\title{
CANNONS AND RUBBER BOATS
}

\author{
Oriana Fallaci and the 'Clash of Civilizations'
}

\section{Francesca Orsini}

School of Oriental and African Studies, University of London, UK

\begin{abstract}
clash of civilizations

contemporary Italy

Islamophobia

Oriana Fallaci

rhetoric

Written in October 2001 as a 'gut reaction' to the attack on the Twin Towers, and published first as a long article in the daily Corriere della Sera and then in book form (in its original shape, twice as long as the article) in December 2001, Oriana Fallaci's pamphlet La rabbia e l'orgoglio ('Anger and pride') was in its twenty-sixth edition when I bought it in September 2004. Its follow-up, La forza della ragione ('The force of reason'), has already sold 800,000 copies since its publication in 2004. Oriana Fallaci has emerged after 9/11 as the strongest and most vocal Italian representative of the 'clash of civilizations' theory. This essay analyses the constitutive elements of her discourse (Italian nationalism, values instead of history and politics, and violent speech conflating Islam, terrorism and immigrants) and tries to understand its appeal and the sources of its authority in Fallaci's career, in order to outline the specific Italian version of the clash of civilizations theory.
\end{abstract}

There is a simple reason why we need to talk about Oriana Fallaci (1929-

1 Translated into English by the author
2006) and her booklet La rabbia e l'orgoglio ('Anger and pride'). ${ }^{1}$ Written in October 2001 as a 'gut reaction' to the attack on the Twin Towers, it was 
herself as The Rage and the Pride, the booklet was published by Rizzoli New York in 2002. There exist also several web translations, i.e., by Letizia Grasso to be found at <http:// www.borg.com/ paperina/fallaci/ fallaci_1.html > ; by Chris and Paula Newman to be found at <http:// www. travelbrochure graphics.com/extra/ oriana_fallaci_ anger_and_ pride.htm >; and at $<$ http:// italian.about.com/ library/fallaci/ blfallaci23.htm >

2 Her previous reportage for Corriere della Sera had been on the Gulf War in 1991. published first as a long article in Corriere della Sera, then in book form twice as long as the original article and with a fifty-page preface - by Rizzoli Editore in December 2001. It was in its twenty-sixth edition when I bought it in September 2004. Rizzoli, which owns the Corriere della Sera/RSC group and has been Fallaci's publisher since 1953, proudly claims that La rabbia e l'orgoglio has been the greatest non-fiction best-seller ever in Italy, selling more than a million copies in the first ten months of publication, and has marketed the book relentlessly. Its follow-up, La forza della ragione ('The force of reason'), has already sold 800,000 copies since its publication in 2004, and the two books are sold together with a self-interview as a trilogy, advertised as a 'gift package'. Its French and German translations also made it to the best-seller list, and by 2002 the book had been translated and published in Spain, Portugal, Holland, Hungary, Israel, Poland, Romania, Korea and the US. La rabbia e l'orgoglio provoked a furore in Italy on its publication, as we will see, and in France its publication by PLON was followed by widespread accusations of racism by 'red fascists' and the 'Parisian press' (Fallaci 2002). While La rabbia e l'orgoglio appeared after a ten-year long silence, after 2001 Fallaci made several appearances in print and on Italian television, intervening famously against the anti-globalization meeting held in Florence, her native city, in November 2002; against the referendum to reform the existing restrictive legislation on artificial insemination; and, most recently, on the London bombings of 7 July 2005 (Fallaci 2005). ${ }^{2}$ A year ago a proposal to nominate her life senator was dismissed by left councillors in Tuscany, and upon her recent death after a lung cancer, a controversy erupted between those who immediately wanted a street in Florence named after her, and those who vehemently opposed it.

In other words, not only Oriana Fallaci emerged after 9/11 as the strongest opinion-maker in Italy on the 'clash of civilizations' theory, but her success and the support from readers indicate that she gave voice to sentiments which find widespread support in Italy's silent majority. Although the question of Islam divides Italians in a way that cuts across traditional political faultines, and although Fallaci's polemic is stridently against all existing Italian political forces, nevertheless the appeal of her polemic to a proud national identity and the defence of Italian territory against immigrants from Islamic countries echoes a discourse on the defence of Italy's, and Europe's, 'Christian roots' that finds favour among wide sections of the Italian clergy (including the current Pope, Benedict XVI), Lega Nord and other members of the centreright coalition, and, most importantly, among many Italians.

This essay will investigate the roots of Fallaci's authority and popularity in the persona she built up over the years through her previous books and articles. It will then analyse the ideological discourse and powerful rhetoric of La rabbia e l'orgoglio, paying special attention to its articulation of national identity. My analysis will follow the development of her arguments 
as they appear in the book, since the structure of her polemic is functional to its content. What is especially pertinent for us explore is the particular ideological configuration the 'clash of civilizations' theory takes on in Italy and the contingent conditions and Italian identity it is predicated upon. Finally, in the light of the readers' responses and letters sent to Corriere della Sera, I will seek to assess the purchase of Fallaci's anti-Islamic tirade and what it can tell us about Italian attitudes towards immigration and Islam.

\section{An eyewitness to history}

3 Her novels, including Penelope alla guerra (1961), Gli antipatici (1963) and Insciallah (1990) were, at least initially, less successful, though Insciallah, which was first serialized in Corriere, won the SuperBancarella prize and has sold 600,000 copies (Zaccuri 1997).
4 Translations from La rabbia e l'orgoglio and from other Italian sources are my own unless otherwise indicated.
If I may start on an autobiographical note, I remember reading Oriana Fallaci's books avidly as a teenager in Italy. I think that Intervista con la storia (1974, 400,000 copies sold) was the first book on contemporary history and international politics that I ever read. Then came her book on the American space mission (Se il sole muore, 1965), followed in succession by her gutsy, prize-winning reportage on the Vietnam war (Niente e cosi sia, 1969, Bancarella prize, 430,000 copies); her heart-wrenching Lettera a un bambino mai nato (1975, 1,250,000 copies) on her naturally aborted baby; and the quasi-novel Un nomo (1979, 820,000 copies), her declaration of love for Alexis Panagulis and political exposé of Greece under military rule. ${ }^{3}$ Every book contributed, as critics have pointed out, to the creation of an autobiographical persona which has been, in writer Michele Prisco's words, her most successful literary creation, i.e., the gutsy, tough war reporter who brings the same toughness to anything she writes about, the young woman who dares to enter a man's world, become a professional journalist and question the most powerful men on earth, and at the same time who is not shy to explore new sexual and emotional territories in ways that seemed to mirror the feminist movement of the 1970s. This reputation for toughness, for brutal sincerity (brutal bence sincere) and for being an eyewitness remained with her. Together, these qualities made up her auctoritas. As in her other texts, in La rabbia e L'orgoglio both the main text and the preface begin with a self-reflexive, autobiographical incipit.

To the Readers:

I had chosen silence. I had chosen exile. Because in America, and the time has come to shout it loud and clear, I live like a political refugee. I live in a political self-exile that I imposed on myself, at the same time as my father did, many years ago. That is, from the time when we both realized that to live side by side with an Italy where ideals lay on the rubbish heap had become too difficult, too painful, and disappointed offended wounded we left behind the great majority of our fellow citizens. (Fallaci 2001: 7) ${ }^{4}$ 
The first part of the main text continues with her personal anger at the many people (?) in Italy as well as Palestine who toasted the attack on the Twin Towers. It was this deeply-felt indignation which prompted her to 'break her silence'. Personal reaction and strong, gut feelings are two of the basic ingredients of the heady mixture of Fallaci's writings.

Another source of her appeal, again thinking back to my teenager self, was the fact that, in an age when political debates and arguments were always couched in an extremely abstract and abstruse language (politichese), Fallaci wrote clearly and directly and made politics a matter of personalities. We must remember that media interviews then were not the ubiquitous phenomenon they are now. It gave a rare frisson to read her direct questioning of Henry Kissinger, Golda Meir or Yasser Arafat, her hammering them until she either got replies or showed that her subjects were shying away from the 'truth' she was after. Fallaci came to the political leaders she interviewed with the common person's distrust of power and lack of interest in political ideologies. Her politics was made of bold and simple ideals freedom, democracy, the fight against dictatorship and injustice. Much was made in those interviews, and in later ones with Khomeini after the Iranian Revolution and with Ghadafy, of the difficulty in getting to the interviewee, of the dangers she exposed herself to, her 'toughness' in not giving up and in standing her own ground. In her interviews with Arafat, Khomeini and Ghadafy, Fallaci was never interested in their ideological arguments - for her they were either fighters ('guerrigliero' is the most generous term she used for Arafat) or dictators, and as such to be despised and exposed as ruthless and, ultimately, vain (see Fallaci 1991, 1979, 1986). The only powerful people she took to were either women leaders such as Indira Gandhi, Sirimavo Bandaranaike and Golda Meir, who, unlike male leaders, were open with her about their personal lives and with whom she developed an empathy apparently based on their common struggle and success in a man's world; or men who were able to convince her that power was not what they were after - 'gentlemen' like Norodom Sihanouk or the Italian Socialist Pietro Nenni, often elderly men with a touch of failure or tragedy about them.

'Toughness' (literally 'balls', 'coglioni'), 'truth' and 'courage' are the badges Fallaci wears proudly in La rabbia e l'orgoglio, the qualities on which she bases her authority and her arguments (she's been there, seen it in person): 'what I am saying is a tough and uncomfortable truth', she often repeats, and the fact that she got attacked so violently and still said it proves that it must be true. The back cover of Oriana Fallaci intervista Oriana Fallaci declares it to be 'the self-interview of a woman who has the courage to write the truth about herself and others', and this is a claim that many of her readers and fellow journalists readily subscribe to. 'Thank you for being an authoritative source', wrote one reader after the 2001 article, 
5 Giuliano Zincone, a columnist for Corriere della Sera, has spoken of an 'explosion of sincerity', by someone 'who has seen many countries and many wars' (2001). because, unlike many who these days claim to be experts on Middle Eastern affairs and pontificate and speculate on such tragedies and draw from them profit, fame and personal advantage, you have seen certain realities, you have touched them with your own hand and you are ready to pay the price in person. (Schiavoni $2001)^{5}$

\section{Fallaci's rough rhetoric}

6 Franco Cardini, a Catholic historian on the Middle Ages who belongs to the centreright but believes that the enmity between Europe and Islam is a historical misunderstanding, wrote in his review of La forza della ragione that most of what Fallaci said was factually incorrect, 'but she writes it with her heart, she writes it with extraordinary power, she writes, despite the occasional lapse, displaying extraordinary stylistic effectiveness. Oriana is not great for what she says because, as I tell her affectionately, she doesn't get anything right really. Oriana is great for how she can say such things, for the force she puts in, for the pride and the fascinating violence she is able to express' (Cardini 2004; emphasis added).

7 Some examples of idées reçues:

Americans are all efficient (Italians are the opposite of
'I like the way she writes. I like her as a journalist', Giovanni Agnelli, Mr Fiat and one of the most powerful men in post-war Italy, is supposed to have said when looking for Fallaci's books at a book fair (Zaccuri 1997). Fallaci's writing style, direct and rhythmic, has been another important source of her widespread appeal. A populist as well as popular writer, she appeals both to readers who have no previous knowledge of the subject and to those who may question her facts but are nonetheless seduced by her style. ${ }^{6}$ An excellent essay on Fallaci's 'rough rhetoric' points to the predominance of the affective over the argumentative style (movere over docere, according to classical Latin rhetoric), her copious use of idées reçues and of examples rather than arguments, and her use of enumerative figures of speech (anaphora, parallelism with climax or anticlimax) (Andreotti 2002; see also Scalea 2005). ${ }^{7}$ This style was already displayed in her previous writings, but in La rabbia e l'orgoglio and her subsequent writings on Islam it is put at the service of a politics of hate. Warning Italians about the possibilities of an Islamic attack, for example, after using repetition and enumeration to evoke the beautiful treasures of Italy and the memories of Nazi outrage, she shifts the register to that of a street fight:

I am no longer young, I was born in the war, I grew up with the war and I know a lot about the war. And I have more balls than you, who in order to find the courage to die must kill thousands including four-year-old girls. You wanted war, you want war? As far as I'm concerned, let's have it. War to the last breath. (Fallaci 2001: $34-5)$

The register, openly colloquial, suggests a kind of rough frankness, while her frequent use of expletives and insults is reminiscent of Lega Nord's political rhetoric (Andreotti 2002). Insults not only show her high level of passion (her 'fascinating violence', as Franco Cardini calls it) but also that she has torn down the 'veil' of hypocrisy and political correctness. In this way, gut feelings become equated with high morality rather than with base reactions.

Hyphenating sentences when she parodies others, confessional and proud when talking about herself and her family, 'masculine' and not shying away from abuse and obscene words to signify her disdain or the barbarity of 
Americans); Americans are all patriots (Italians are the opposite); America is a young country - in the nineteenth century it was still building its identity (Italy is an old country - its identity can no longer be modified); Ancient Romans 'enjoyed watching Christians being mauled by lions' but others, Fallaci employs a style in La rabbia e l'orgoglio that has the urgency of war reporting and is very powerful indeed. As one journalist commented, the force of her rhetoric aims and succeeds at shaking the reader out of complacency or cynicism. Indeed, the continuous use of military metaphors and the praise for men (and women) with 'balls', the aggressive and abusive tone and the attitude that 'you can't argue with these people', all push towards a confrontational attitude and a military resolution. In brief, Fallaci's is an example of what Kumkum Sangari has called the 'rhetoric of incitement', a form of indirect agency in which a woman berates men for their supposed effeminate hesitation to fight and claims she will fight instead (Sangari 1999: 364-489). ${ }^{8}$

\section{Proud of being Italian}

'a long time has gone by and we have become a little more civilized'; Christians 'enjoyed watching heretics being burned at the stake'; 'some' Islamic immigrants work 'because Italians have become so spoilt [signorini]' (Fallaci 2001: 1, 2, 4, $5,23,24,25,26)$.

8 Sangari writes in the context of Hindu right-wing mobilization in India, led by sadhvis or holy women who perform this leadership function.

9 Her statement that 'to live side by side with an Italy where ideals lay on the rubbish heap had become too difficult' is somewhat cryptic. The 'moral question', i.e., the critique of corruption and other signs of moral degradation in the Italian body politic,
Though inseparable from the rhetoric they are couched in, it is to her arguments and ideas that we must now turn, for they too aroused a powerful echo in her readers.

The genealogy that Oriana Fallaci claims for herself, and for the Italy she purports to speak for, is nationalist and libertarian - it is a secular and beroic line that joins the Risorgimento with anti-fascism. In the preface to $\mathrm{La}$ rabbia e l'orgoglio she represents herself as a 'political self-exile' in New York, following in the footsteps of Garibaldi and Piero Maroncelli, Federico Confalonieri and other 'patriots' before him, and of anti-fascist intellectuals like Gaetano Salvemini, the historian who warned Americans against the threat of Nazi-fascism in a speech in New York in 1933. The parallel is made explicitly: just as Salvemini warned Americans in 1933, she is now warning the West about the danger of Islam. New York is of course a powerful location to be writing from in September 2001, but her invocation of Italian political exiles lends her the peculiar authority of a misunderstood prophet though, as we have seen, her self-imposed exile is due to her own moral disgust towards post-war Italy rather than to any actual political persecution. ${ }^{9}$ In this respect, Fallaci's nineteenth-century patriotism differs from other 'long-distance nationalisms' in that it is not the product of a diasporic community longing for an imaginary homeland.

References to her childhood in a ferociously anti-fascist home form a recurrent topos in Fallaci's texts, in her interviews as well as the more recent pamphlets. La rabbia e l'orgoglio is dedicated to her parents, Edoardo and Tosca Fallaci, 'who taught me to tell the truth', and to her uncle Bruno Fallaci, a journalist and editor of the magazine L'Europeo, who first introduced Fallaci to journalism 'and taught me to write the truth'. 'Exile requires discipline and consistency', she writes, two virtues she inherited from her parents (Fallaci 2001: 13). Invoking her loyalty to her parents and 
has a very long history in Italian politics, not least within the longruling party, Democrazia Cristiana. It is therefore amenable to many political viewpoints.

10 Despite this, Lega Nord has passionately championed Fallaci's book, to the point of distributing it free during a demonstration against the proposal to give immigrants legally resident the vote in local elections, held in Milan on 6 November 2003 (see $<$ http://www. stranieriinitalia.it/ notiziario2/ n3880.html >). their political morality becomes a way for Fallaci to claim an unbroken line between those moral values and her own current standpoint, bypassing any ideological inconsistency or in fact any change of mind that may have intervened and that may be apparent to critical readers. (As Neelam Srivastava's article points out, the Italian Resistance, especially on the left, was deeply sympathetic to anti-colonial and anti-imperialist movements.) Less critical readers, however, accept the moral passion at face value, 'a testimonial of the highest moral sensitivity', in the words of one reader (Albert 2001).

The heroic, sober and high-minded Italy of the Risorgimento and the antifascist Resistance, Fallaci's argument goes, lost out after the war to the 'other' Italy, the Italy of trasformismo and opportunism, of self-interest and narrow-mindedness. While we would expect the barb to be directed at the erstwhile ruling party, Democrazia Cristiana, left-wing intellectuals ('deluxe cicadas', according to Fallaci) come in for much criticism, too (Fallaci 2001: 40-1). Above all, they are guilty of buonismo and of short-sighted sympathy towards Palestinians and immigrants. In fact, Fallaci is explicit in her disdain for Berlusconi and for Bossi's Lega Nord, who are guilty of rubbishing the nationalist ideals of Risorgimento embodied in the nineteenth-century tricolour flag ridden with bullets and smeared with blood that she keeps 'for company' in her Manhattan flat (ibid.: 65). ${ }^{10}$

As the above makes clear, Fallaci's political position cannot be defined in clear party terms and this reinforces the perception that hers is a discourse of values, not of politics. Values, needless to say, are much more amenable to division into simple binaries, good versus bad. As all her critics have observed, Fallaci's views are simple and Manichaeistic: good versus bad, freedom fighters versus authoritarian dictators, etc. Historian Luciano Canfora's critical pamphlet on the limits of the rhetoric of democracy observes that one of the inherent 'problems' of democracy is that it is a complex system while those who vote often prefer matters to be plain and simple and have little time for complexity (Canfora 2002). Many of Fallaci's readers identify her with the spirit of the late Indro Montanelli and praise their 'free, liberal spirit which knows how to break the buonismo of a left which is too often disconnected from reality', as one reader put it:

Yesterday, when communism was a concrete danger, Montanelli was not afraid of being called a fascist; today, when in the new international order the world is divided between those who are in favour of terrorism and those who are not, Fallaci is not afraid of being called a racist. Her article - a visceral shout - is a well of truth. (D'Elia 2001)

Fallaci's discourse of values (instead of politics) is clear above all in her treatment of the United States. America is a nation 'born out of the idea of 
11 Fallaci's hero in October 2001 is New York's major Rudolph Giuliani, another ItaloAmerican 'with balls' (2001: 65). freedom' and it has taught the idea of freedom to the rest of the world (Fallaci 2001: 71). It is a 'young' country which has provided a haven and redemption to the working masses of the world. The 'Liberated Masses' are the great strength of the United States, argues Fallaci, because no one can beat down the energy of a people made up of working men who have achieved their goals (ibid.: 75). This is why Americans are able to unite and strive together, and the flag is the symbol of their unity of purpose. ${ }^{11}$ America, in other words, is what Italy could, but never quite manages to, be. And it is the Italians' proverbial lack of love for their flag and their tendency to criticize one another even in times of need that condemns them to failure. This 'difficult patriotism' is an important point and worth spending a few words on here, since it emerges also in readers' responses to Fallaci.

Mussolini's roaring nationalism and Italy's aggressive warfare were subject after the war to several kinds of critical distancing. While in terms of the ruling class the post-war regime under Democrazia Cristiana rule represented a significant continuity with fascism, ideologically the new Republic was vehemently anti-fascist (as inscribed in the new Constitution). The experience of the Resistance was appropriated as the national foundation myth, so that the new Republic could view itself as having fought against Mussolini and having won freedom along with the Allied armies. The values of the Resistance were - especially as filtered through the literature of Beppe Fenoglio and Italo Calvino, the oral histories of Nuto Revelli and films by Roberto Rossellini and Carlo Lizzani - decidedly antiheroic and anti-nationalist. Italian comedy (and later a film like Fellini's Amarcord) made fun of fascist nationalism, espousing instead the allegedly Italian values of individual self-preservation and indifference to all patriotic appeals as our saving grace: Tutti a casa ('All home', Luigi Comencini, 1960) is the title of a film on Italian soldiers deserting at the end of the war. In a similar process of critical distancing through comedy and satire, Italians were represented as not having been as anti-Semitic as the Germans nor as snobbishly racist as the British ('Italiani brava gente'), a myth that Fabrizio del Donno explodes in his contribution to this issue.

Nationalism in post-war Italy found legitimate expression only in sport, until Bettino Craxi as Prime Minister in the 1980s revitalized national pride as a legitimate feeling - significantly also through the Italian 'peace-keeping' mission in Lebanon that Fallaci celebrated in her novel Insciallah. After Craxi, it fell upon his acolyte Silvio Berlusconi to transform football's national pride into a political slogan ('Forza Italia'). National pride is a guiding value of Forza Italia and of Alleanza Nazionale, while the third party in the coalition, Lega Nord, has long called for regional autonomy. Thus, Oriana Fallaci's declared patriotism, the 'lump in the throat' she feels on seeing the flag and her call for patriotism - in terms of mobilization against a common threat and of pride in Italy's distinguished past - invoke a 
sentiment which has had little public legitimacy in the past decades and, judging from the readers' responses, whose illegitimacy seems to have left a gaping hole, a need in many an Italian (Fallaci 2001: 136).

\section{'Them'}

12 It was the sweeping quality of her belief that alienated even someone like Magdi Allam, vice-editor ad personam of Corriere della Sera, who otherwise admired her and felt honoured by her friendship (Allam 2005).
All Islamic states, according to Fallaci, harbour terrorists, and if they are not obviously fundamentalist dictatorships they are so just below the surface ('gratta gratta') (Fallaci 2001: 118). The enumerative style is put to effective use to suggest that the totality of countries where Muslims live as a majority are all equally undemocratic, undoubtedly for the same reason: '[f]rom Afghanistan to Sudan, from Indonesia to Pakistan, from Malaysia to Iran, from Egypt to Iraq, from Algeria to Senegal, from Syria to Kenya, from Libya to Chad, from Lebanon to Morocco, from Palestine to Yemen, from Saudi Arabia to Somalia' (ibid.: 23). The list is compelling, and to the reader overwhelmed by news of bombs and unrest in all these countries it will be convincing enough. After all, it is only 'the so-called experts who pontificate', as one reader put it, who will insist that each country is a particular case, that some are not Islamic states at all, that each makes a different political use of Islam, etc.

'Usama bin Laden and the Talebans are only the most recent manifestation of a reality which has been going on for the last 1400 years', states Fallaci (ibid.: 117). Originality is not the most striking characteristic of her attitude to Islam. We have all heard similar statements in the past five years. What is striking is how she fuses together very different entities: secular fightersturned-political leaders like Arafat, fundamentalists like Khomeini and the Taleban (one Shia, the other Sunni, by the way), 'radical' leaders like Ghadafy, and all Muslim immigrants into Italy and all Muslims worldwide. They are all dangerous, all real or potential terrorists because they believe in Islam. This is the most obviously orientalist quality of her discourse, the idea that Islam as an essentially and unchangeably barbarian religion that motivates all its believers into a fanatic hatred for the West which overrules all other possible impulses. ${ }^{12}$ What is peculiar to her argument is the tone and the retrospective view on all the Muslim personalities she had met and all the Muslims she had ever encountered or read about, and how they connect with attitudes to Muslim immigrants to Italy, whether clandestine or lawful and working residents. It is an attitude which Fallaci speciously refuses to accept as racist 'because you cannot be racist against a religion' (ibid.: 80). The tone, used with the authority of someone who has 'been there' and is 'never afraid to speak the truth', lends legitimacy to the common anti-Islamic rant of the 'man-in-the street' and makes any kind of nuanced or measured assessment look like a well-meaning (buonista) sham. 
13 For a detailed reply to Fallaci's assertions, see El Sebaie (2004a).

14 'Toasting the horror', like Marie Antoinette's mot about croissants, is an urban myth: Italians also are said to have rejoiced in a similar way, a falsehood that was pointed out by another participant in the debate, Dacia Maraini.
The boundaries of licit political discourse are shifted in the process, and what was unspeakable or could be said only among like-minded people can now be written on the pages of the most illustrious Italian daily. Anyone who wishes to get the full flavour of her explicit hate speeches towards Muslims should look at one of the websites with the English translation of La rabbia e l'orgoglio.

Arafat, Khomeini and Ghadafy are all alike in La rabbia e l'orgoglio, all examples of bloodthirsty, ruthless and fanatical Islamic dictators. Despite the alleged consistency, this is not even what Fallaci herself wrote in her original interviews. Islam is never mentioned in the 1972 interview with Arafat. Rather, the contrast between them is of 'an Arab who believes in war and a European who no longer does so'; a leader who is 'all wrapped up in his law of retribution, eye-for-eye and tooth-for-tooth', and an atheist who is nonetheless 'steeped in Christianity, in its hatred for hatred' (Fallaci 1991: 148). In La rabbia e l'orgoglio Arafat becomes the bawling and salivaspitting precursor of today's Islamic terrorists. Addressing him directly in the text, Fallaci now responds to the claims Arafat had then made about his superior culture, taking arithmetic as an example, and rubbishes them (Fallaci 2001: 87). ${ }^{13}$ Arafat was not only discourteous to Fallaci but also seemed to her to personify the aggressive, ignorant, 'macho' and obscurantist Islamic leader/terrorist (though he himself was the leader of the non-Islamist, secular group al-Fatah). Palestinians are fixed in her mind once and for all as those who 'toasted' the bombings in Lebanon that killed hundreds of Americans and French, and who went on to 'toast' the fall of the Twin Towers fall. ${ }^{14}$ Duplicitous and arrogant, they are the insidious enemies the brave Italian soldiers of the peace corps in Lebanon were called to defend (and the Italian left's sympathy and support for the Palestinian cause thus becomes a short-sighted and hypocritical - if not suicidal - choice). Either Fallaci's view of Arafat and of Palestinians in general changed after Lebanon - and she claims that her 1990 novel Insciallah, though a novel, 'is based upon historical reality' - or in 1972 it was not licit to use this kind of language (Fallaci 2001: 118). Her claim of 'I've been shouting this for twenty years' indeed suggests that Lebanon was the turning point (ibid.: 79).

The 1986 interview with Ghadafy, amply reported over four days, was all about the vanity and almost deranged ruthlessness of a dictator who believed he was the saviour of his country and financed all sorts of international terrorism, yet there is no mention of Islam. Interestingly, when Ghadafy tried to mention Italy's colonial invasion of Libya, Fallaci was not prepared to listen ('but that was 70 years ago!') (Fallaci 1986: 14). In La rabbia e l'orgoglio her interviews with Arafat, Ghadafy and Khomeini are quoted in support of her view that 'Islamic leaders' are all the same, either misogynist or lecherous or both. 


\section{Art as value}

15 Sherif El Sebaie (2004b) carefully refutes the claim that Islamic culture contributed nothing to Italy by pointing to the many Islamic artefacts in Italy.

16 As Luciano Andreotti has astutely pointed out, 'Fallaci's method of presenting "our civilization" through indiscriminate lists of great names suggests only occasional familiarity' and recalls Furio Jesi's definition of what he called the 'exoteric' or 'profane' Right's approach to art. For the 'profane' Right, artworks and authors do not provoke problematic selfquestioning or critical approaches. They are 'valuable stuff' (roba di valore), with no internal, historical or sociological difference. This attitude towards art is characterized by the repulsion for history that is camouflaged as veneration for a glorious past' (Jesi 1979; cited in Andreotti 2002).
In La rabbia e l'orgoglio, Fallaci engages directly with the 'clash of civilizations' theory. As a matter of fact, she rejects the term since she cannot countenance 'putting [both civilizations] on an equal footing, as if they were two parallel realities of equal weight and measure' (Fallaci 2001: 85 ). Instead, as if weighing the two 'civilizations' on a scale, she puts on one side Greek civilization (Homer, the Parthenon, the philosophers), ancient Rome, even Jesus ('who taught us the concept of love and justice'). She reluctantly includes the Church, for despite the Inquisition and her own anticlericalism it cannot be denied that the Church also produced all those wonderful churches and paintings. Western classical music, science and technology complete the score (ibid.: 86). And on the other scale, in 'the other civilization of guys with frocks and turbans'? 'After much searching here and there, one can only find Muhammad and the Qur'an, Avicenna (Ibn Sina) and Omar Khayyam the mathematician and poet.' 'Stop bawling', she now addresses Arafat directly, 'your grandfathers only gave us a few beautiful mosques and a medieval religion' (ibid.: 88$).{ }^{15}$ The Taleban's destruction of the Bamiyan Buddhas ('my Buddhas') is taken as exemplary of what Islam does to art. And then we are back to the Palestinians in Beirut and their desecration of Christian holy objects, as is faithfully 'described' in her novel Insciallah. ${ }^{16}$

Fallaci's argument about art serves not just to prove the superiority of Western civilization but also as a point of connection with the second half of La rabbia e l'orgoglio. This consists of a violent reaction to the 'threat' of mass immigration into Italy. The emblematic case (exemplum) she brings here is the sit-in organized by Somali (ex-colonial!) immigrants in Piazza del Duomo in Florence to protest against the failed renewal of their residence and working permits and the denial of their right to bring their family members to Italy. Fallaci did her best then to urge the mayor and the Minister of Foreign Affairs to dislodge them, but though these figures privately agreed with her (she claims), they refused to act, paralysed by the fear of being called racist. Fallaci finally called the head of police and threatened to go and set fire herself to the tent and its occupants. The police dismantled the tent the next day.

\section{'Cannoni o gommoni'}

Perhaps the most significant point in Fallaci's Italian tirade, then, is how the attack on the Twin Towers by a fringe of Islamic terrorists is not only linked to the unchanging and barbaric 'sons of Allah', but also brought nearer home by identifying it with immigration from the south and east 
of the Mediterranean. Once again, no distinction is made here in her enumerative list: Sudanese, Bangladeshi, Tunisians, Algerians, Pakistanis, Nigerians are all alike (Fallaci 2001: 122). The discourse here becomes the familiar one of Lega Nord xenophobia. First, all these immigrants are criminal, and arrogant blackmailers to boot: if one objects to anything they do, they say: 'I'm aware of my rights'. They are all terrorists (mosques in Italy are terrorist cells, and 'behind every terrorist there is an Imam') (ibid.: 126).

Significantly, Fallaci even refuses to call them 'manual workers' or to equate them with the scores of Italian emigrants to America at the beginning of the twentieth century, an important part of Italian historical memory. That was a 'legal' migration, she claims erroneously, this is illegal (ibid.: 129). Moreover, now the border police, who should send them back, 'welcome them with open arms, like Dame di San Vincenzo' (ibid. 128). How can Fallaci praise the US as a crucible of peoples and then be so hostile to immigrants into Italy? Because whereas the US is a 'young country' (she feels of course no need to mention Native Americans), Italy is 'three thousand years old' and a monocultural country (ibid.: 129-30). Immigrants by definition threaten its cultural identity. Far from seeking to accommodate them, the Italian government should just send them packing. As we shall see below, many of these arguments form part of the current Italian debate on Islam in Italy and echo feelings expressed by Lega Nord and by sections of the Catholic Church. In visual terms, too, immigrants and Islamic fundamentalists overlap in the image of the illegal immigrants (clandestini) who protested in the Italian square. As she pithily concludes, if these 'friends of Bin Laden' invade 'my Italy', whether they do so with gommoni (rubber boats) or with cannoni (cannons), 'it's the same thing' (ibid.: 162).

\section{Gaps, silences}

Wordy and comprehensive, Fallaci's apocalyptic sermon nonetheless shows several important gaps and silences. These gaps and silences mostly take us back to the lack of 'colonial awareness' in contemporary Italy that the editors of this issue lament, and to the fact that the discourse of decolonization was carried out only by the Italian left (see Neelam Srivastava's article in this volume). The most obvious thing lacking in Fallaci's discourse is politics, and with it history. The absence of politics is also the absence of looking into the internal history and vicissitudes of the postcolonial states of North Africa, the Middle East and Asia - the difficult paths of economic development, the disappointment with the westernized nationalist elites, the extremely ambivalent attitudes towards the 'West' as 
17 This section is based on Renzo Guolo's excellent book Xenofobi e Xenofili: Gli Italiani e l'Islam, which deserves to be translated into English.

18 Associations and centres are divided into those representing 'state Islam' (mainly of Saudi Arabia and Morocco), Islamist groups like the Muslim Brotherhood, some Jihad groups which have used some Italian mosques and Islamic centre as hiding places (as an imagined 'other'. Retrospectively, Fallaci forgets that Arafat (and George Habash) belonged to secular organizations, that President Assad and Saddam Hussein did not establish Islamic regimes, and so on and so forth. Only if one forgets all this can one indeed ask, with Fallaci and Bush, 'why do they hate us?' and answer, 'because they secretly envy us' (Fallaci 2001: 25). It will not do to answer Fallaci's oversimplifications with other oversimplifications. As journalist Tiziano Terzani pointed out in his thoughtful reply to Fallaci's original article in 2001, this is a great occasion to stop and rethink; and our duty as intellectuals is to create 'fields of comprehension instead of fields of war' (Said's phrase). The journalist's task is to simplify that which is complicated, but one should not go too far (Terzani 2001). Instead, by placing the discourse on the level of values rather than politics, Fallaci and her readers continue to forget history and international politics, the exploitative and manipulative role that Italy (one of the biggest arms producers in the world), the US and other Western countries continue to play on the world scene. Instead, the 'West' can present itself as a hapless victim, the victim who of course now should rediscover its toughness, its 'balls'.

\section{Italians and Islam}

Fallaci also

recounts), Italian converts to Islam who often play a prominent role in associations as they can be legitimate interlocutors for the Italian state, and finally 'phantom' Islamic representatives (like the convert Adel Smith) who have been created by the media and acquired a fame

disproportionate to their real significance. Guolo views most of the demands of organizations like the Unione delle Comunità e Organizzazioni Islamiche in Italia
Arguably, the connection between Islamic terrorism and immigration is a key to the pamphlet's success. As such, La rabbia e l'orgoglio is an intervention in the difficult and complex relationship between Italians and Islam. This final section presents a brief overview of the positions and players in the debate on Islam in Italy in order to understand where Fallaci is located and why she has gained such prominence. ${ }^{17}$

As a vehicle of cultural and religious difference, Islam presents a problem to Italian society, argues sociologist Renzo Guolo, and brings it back to other dilemmas: the still unresolved issue of Italian identity versus national identity, the approach a democracy should take when confronting individuals and groups carrying values that are potentially alien to its own, and so on. Islam - far from monolithic in Italy - divides the left between universalists and multiculturalists, it divides the Church between supporters of Vatican Council II and traditionalists, and the right between antiglobalists and Catholics (Guolo 2003: v). ${ }^{18}$

Despite its many invasions, Guolo continues, or perhaps because of them, Italy is a culturally closed and fundamentally monocultural country. It has neither gone through wars of religion nor through the pacts that usually put an end to them. Therefore, it has not learnt to live with difference (ibid.). Moreover, the short-lived colonial experience did not leave a mark, a memory of 'other' cultures, apart from colonial stereotypes and ghettoiza- 


\section{Francesca Orsini}

(UCOII) - i.e., freedom of religious practice, halal butchers, religious presence in army barracks and hospitals, the possibility for Muslim women to wear the veil in official (i.e., passport) photographs - as unproblematic and easy to realize in practice. What he finds problematic are demands connected with family law (i.e., polygamy) and for community mediation in the relationship between the state and Muslim individuals, and the issue of representation (Guolo 2003: ch.1).

19 Although after one of the Somali suspects of the London bombings was arrested in Rome, the local Somali immigrant community (overwhelmingly Christian) was keen to emphasize not only the different, and older, history of their immigration, but also the fact that Christians and Muslims in Somalia had lived together for centuries, explicitly offering themselves to Italians as a model of peaceful coexistence (Rai 3, evening news, 6 August 2005). tion. Significantly, Italy's colonial experience has not produced the kind of 'return migration' that other countries, such as France and Britain, have experienced - no less traumatic for national identity, but with more significant direct links between the former colonies and the former 'motherland' ${ }^{19}$ Thus, initially Italy tried to blank out the reality of the new migratory waves and view them as just a temporary phenomenon. When it finally did focus on immigration, it was only through the lenses of Italian economy and internal security, i.e., no attention was paid to the cultural dimension of mass immigration. Migration, especially from Muslim countries, generated deep social anxiety, but because to raise the problem would have meant admitting that migrants were there to stay, the anxiety was not publicly and politically addressed (ibid.: vi). As the number of migrants grew, Italians became divided between a large 'party of exclusion' and a tenacious 'party of inclusion', a division that did not follow the usual political faultlines.

Guolo is rather scathing of the buonismo of the multiculturalist left, including Rifondazione Comunista and anti-globalization groups. In his view, their 'spontaneous inclusivism' overlooks the real 'other' in the name of an idealized 'other'. It fails to recognize that individual 'others' may not want to integrate in the way the inclusivists suggest and that there is a big difference between internal minorities (social or ethnic) and external minorities. Further, '[n]aive multiculturalism harms the left, particularly in its relationship with society which does not identify with its well-meaning but ideologically integrationist messages' (ibid.: 40). In the eyes of a society so afraid of the future as to become an 'anxious society', the Italian left has become identified with the active and willing construction of a multi-ethnic society, and moreover in ways that will only benefit those who are not willing to give up their cultural identity, in this specific case 'the Muslim' (ibid.).

'On the left, a phenomenon with such a problematic social impact as immigration', he argues,

has been represented, almost obsessively, under the 'reassuring' formula of the meeting of cultures, as mutual enrichment, as redemptive contamination. For the theoreticians of multiculturalism it was almost an unimportant detail that in the popular peripheries of Milan or Turin, or in the huge industrial periphery of the north-east, this meeting appeared neither enriching nor redemptive. (ibid.: 41)

Multiculturalists superciliously dismiss phenomena of social rejection as 'regressive', often without analysing their motives. But actually anti-Islamic reactions, however pathological, reveal the contradictions within emerging multi-ethnic societies. They reveal the limits of Western universalism and the 
20 Guolo gives a very interesting analysis of Lega Nord's Islamophobia in its political homeland in the Italian industrial north-east, where entrepreneurs require immigrants for their workforce and where Lega Nord's critique of immigration, and of the globalized economy that produces it, goes against its own political and social base. Many former Lega Nord voters have since moved to Forza Italia, but Lega Nord's continued Islamophobia finds echoes within them and produces confusion in the local political system, while pragmatically local entrepreneurs need (for example) to build homes for immigrant workers, who in that workrich region need houses more than jobs (Guolo 2003: 76-9).

21 For example Giovanni Sartori, professor of political science, is critical of multiculturalism and believes that acquiring citizen status does not automatically entail integration: instead immigrants should be 'acculturated' into Western values, most realistically not in the first generation but in the second generation, through question of identity, and bring us back to the crisis of public space, all elements related to globalization (ibid.: 42).

The Italian right has been ambivalent towards Islam. While Berlusconi welcomed Turkey's entry into the EU but claimed that 'Western civilization is superior', Forza Italia's Home Minister Pisanu sounded a lone note of pragmatism in his proposal for an institutional 'pact' between the state and its Muslim residents, and Alleanza Nazionale's Foreign Minister Gianfranco Fini was the first to suggest that immigrants legally resident should be allowed to vote in local elections, creating a furore (ibid.: 48-9). But it is the third member of the coalition, Lega Nord, which has turned xenophobia into a major political platform. In a critique of economic globalization that paradoxically brings this party close to the left-wing anti-globalization movement, Lega Nord defends Italy's 'Christian roots' and indulges in open racism. On the ground, it has led campaigns against local mosques, at times against the wishes of churches locally. Public pronouncements by Lega Nord figures ('all foreigners are criminals', 'Muslim invaders'), often depicted as 'amusing' or 'outlandish' in the media, have produced a 'huge linguistic and political break', according to Guolo, legitimizing a kind of language previously shunned by all political elites, whether ruling or opposition (ibid.: 70). It is a language very close to Fallaci's also in its use of the colloquial register and slang. ${ }^{20}$

As for the Italian Church, while Pope John Paul II favoured religious dialogue and many parishes have welcomed immigrants and tried to find accommodation and prayer halls for them, a less 'open' line has been dominant at the top of the Italian clergy, especially in the influential person of Cardinal Ruini, the President of the Council of Italian Bishops (CEI) and that of Bologna's Cardinal Biffi, who has unequivocally denounced Islam as the 'enemy of Christianity', suggested that Muslims embody a 'different kind of humanity' and proposed that immigrants should be screened according to their religion (ibid.: 87-92). The new Pope, already critical of the 'ideology of dialogue' supported by Milan's former cardinal Carlo Maria Martini, has vocally articulated the need for Europe to return to its 'Christian roots'. Finally, among influential 'opinion-makers', the critics (Giovanni Sartori, Gianni Baget Bozzo, Fallaci) are a majority. ${ }^{21}$

This overview of the range of positions vis-à-vis Islam and immigration among the Italian left, right, the Church and opinion-makers helps us locate Fallaci's discourse and recognize how, if elements of it can be found elsewhere in the Italian political and cultural landscape, her combination is nonetheless original and powerful. The combination, especially of Islamic terrorism and immigration, has its own explanatory power, which may account for the fact that after the publication of her 


\section{Francesca Orsini}

schooling (Guolo 2003: 101-4). The priest-cum-political scientist Gianni Baget Bozzo instead opposes Islam as an essentially antiChristian religion, a view shared by a significant part of the Italian Church, as we have seen (ibid.: 108). A notable exception is the medieval historian and prolific author Franco Cardini, who believes that the enmity between Europe and Islam is a historical misunderstanding and that Islam can in fact provide an antidote to a secular

West that is adrift (ibid.: 114). article many readers wrote in saying that it had 'clarified their ideas' on the subject.

Bad language, familiar from Lega Nord discourse, is here 'ennobled' by the authority of the speaker and the gravity of the event, so much so that readers spoke of 'high moral sensibility' and hyperbolically called La rabbia e l'orgoglio 'one of the most exceptional statements ever written on our world and on the West' (Rigoldi 2001). The venomous attacks on immigrants and on left-wing buonismo feed into widespread social anxieties and anger at the left's perceived naivety and culpable enthusiasm for a multiethnic society. The (atheist) defence of Italy's 'Christian roots' has found favour among both Church and secular quarters, while Fallaci's passionate patriotism fills a vacuum that political bickering and a long-standing suspicion of nationalism have left in many Italians.

\section{References}

Albert, Alain (2001) 'Ecco la nostra civiltà' (reader's letter), Corriere della Sera (2 October): 14.

Allam, Magdi (2005) Vincere la paura, Milan: Mondadori.

Andreotti, Luciano (2002) 'Il linguaggio della Fallaci: deformazione e stravolgimento', at < http://www. kelebekler.com/occ/fallaci.htm >

Canfora, Luciano (2002) Critica della retorica democratica, Bari: Laterza.

Cardini, Franco (2004) 'La Fallaci Bis è già un classico (a modo suo)', L'Avvenire (3 April), at < http:// www.kelebekler.com/occ/fallaci.htm >

D’Elia, G. (2001) 'Lo spirito libero ritrovato' (reader's letter), Corriere della Sera (2 October): 14.

El Sebaie, Sherif (2004a) "Zero" in storia alla Fallaci', at < http://www.kelebekler.com/occ/ fallaci.htm $>$

— (2004b) 'L'arte fallace di cancellare la Storia', at: $<$ http://www.kelebekler.com/occ/fallaci04.htm >

Fallaci, Oriana (1979) 'Interview with Khomeini', Corriere della Sera (26 September): 1-3.
_ (1986) 'Io e Gheddafi', Interview with Ghadafy, Corriere della Sera, 21-4 April.

_ (1991) Intervista con la storia, Milan: Rizzoli.

(2001) La rabbia e l'orgoglio, Milan: Rizzoli.

- (2002) 'Eppure con la Francia non sono arrabbiata', Corriere della Sera (8 June): 1.

- (2005) 'Il nemico che trattiamo da amico', Corriere della Sera, 16 July.

Guolo, Renzo (2003) Xenofobi e xenofili: Gli Italiani e l'Islam, Bari: Laterza.

Jesi, Furio (1979) Cultura di destra, Milan: Mondadori.

Rigoldi, Gianfranco (2001) Reader's letter, Corriere della Sera (2 October): 14.

Sangari, Kumkum (1999) Politics of the Possible: Essays on Gender, History, Narratives, Colonial English, New Delhi: Tulika.

Scalea, Daniele (2005) 'Il piccolo breviario dell'odio', a review of Oriana Fallaci intervista se stessa, at <http://www.kelebekler.com/ocd fallaci.htm $>$ 
Schiavoni, Simone (2001) 'Finalmente una fonte autorevole' (reader's letter), Corriere della Sera (2 October): 14.

Terzani, Tiziano (2001) 'Lettera da Firenze: il sultano e San Francesco', Corriere della Sera (8 October), at $<$ http://www.kelebekler.com/occ/fallaci04.

htm $>$
Zaccuri, Alessandro (1997) 'La reporter che racconta di sé', Letture $541<$ http://www.stpauls.it/letture 00/1197let/1197le121.htm >

Zincone, Giuliano (2001) 'I coltivatori di dubbi e la spada di Oriana', Corriere della Sera (17 October): $16<\mathrm{http}: / / \mathrm{www}$. stranieriinitalia.it/notiziario2/ n3880.html > 
Copyright of Interventions: The International Journal of Postcolonial Studies is the property of Routledge and its content may not be copied or emailed to multiple sites or posted to a listserv without the copyright holder's express written permission. However, users may print, download, or email articles for individual use. 